\title{
PENGARUH STATUS SOSIAL EKONOMI ORANG TUA, LITERASI EKONOMI DAN PERCAYA DIRI TERHADAP MINAT WIRAUSAHA SISWA SMP NEGERI DI KECAMATAN TENGGILIS MEJOYO SURABAYA
}

\author{
Muhammad Thohir, Yoyok Soesatyo, Harti \\ Muhammadthohir925@yahoo.co.id
}

\begin{abstract}
ABSTRAK
Penelitian ini bertujuan untuk mengetahui Pengaruh Status Sosial Ekonomi Orang Tua terhadap minat wirausaha siswa Pengaruh Literasi Ekonomi terhadap minat wirausaha siswa, Pengaruh Percaya Diri terhadap Minat Wirausaha Siswa, dan Pengaruh Status Sosial Ekonomi Orang Tua, Literasi Ekonomi dan Percaya diri terhadap Minat Wirausaha Siswa secara parsial ataupun bersama - sama / simultan di SMP Negeri Kecamatan Tenggilis Mejoyo Surabaya.Penelitian ini adalah penelitian dengan menggunakan analisis regresi linier berganda dengan pendekatan kuantitatif.Populasi penelitian sebanyak 686 siswa dan sampel 253 siswa yang di ambil secara proporsional random sampling, sebanyak 140 siswa dari SMP Negeri 17 dan 113 siswa dari SMP Negeri 39 Surabaya. Berdasarkan hasil penelitian dan diskusi hasil penelitian dapat disimpulkan bahwa Status Sosial Ekonomi Orang Tua, Literasi Ekonomi, dan Percaya diri berpengaruh signifikan terhadap Minat Wirausaha.
\end{abstract}

Kata Kunci: Status Sosial Ekonomi Orang Tua, Literasi Ekonomi, Percaya Diri dan Minat Wirausaha.

\begin{abstract}
This analysis to know the determine the effect of Socioeconomic Status of Parents of the students 'entrepreneurial interest, Effect of Economic Literacy for students' entrepreneurial interest, Effect on Interest Entrepreneurial Confidence Students and the Effect of Socio economic Status of Parents, Economic Literacy and self Confidence toEntrepreneurial Student Interests with partial and collectively together/simultaneously in SMP at Mejoyo Tenggilis Subdistrict Surabaya. This study is using multiple linear regression analysis with a quantitative approach.The study population of 686 students and a sample of 253 students was taken by random sampling propotional.Based on the results of research and discussion of the results of this study concluded that the results the SocioEconomic Status of Parents, Economic Literacy, and Self Confidence influence the Entrepreneurial Interests with significant.
\end{abstract}

Keywords: Socioeconomic Status of Parents, Economic Literacy, Self Confidence and Interests Entrepreneurial

\section{PENDAHULUAN}

Kebervariasian tingkat sosial ekonomi orang tua, literasi ekonomi, dan percaya diri di SMP Negeri di Kecamatan Tenggilis mejoyo Surabaya menjadi hal yang menarik untuk dijadikan obyek penelitian terhadap minat wirausaha siswa. Dari hasil obeservasi sementara dengan menyebarkan beberapa angket pada siswa di SMP Negeri 17 Surabaya, terhadap perofesi atau pekerjaan yang diinginkan 
setelah lulus SMA atau Perguruan Tinggi diperoleh hasil: 10\% siswa memilih Pengusaha, $10 \%$ siswa memilih Perkantoran, $40 \%$ siswa memilih PNS/POLRI/TNI, $10 \%$ siswa memilih Pengusaha dan PNS/POLRI/TNI, 30\% siswa memilih Perkantoran dan PNS/POLRI/TNI, dan yang memilih buruh Pabrik tidak ada.

Sedangkan di SMP Negeri 39 Surabaya diperoleh hasil; 60\% siswa memilih Pengusaha, $10 \%$ siswa memilih Perkantoran, 10\% siswa memilih Pengusaha dan Perkantoran, 20\% siswa memilih PNS/POLRI/TNI dan Perkantoran, untuk yang memilih PNS/POLRI/TNI saja, atau Buruh saja tidak ada.

Melihat hasil sementara pada observasi di dua sekolahan dapat diambil kesimpulan, bahwa siswa di SMP Negeri 17 lebih cenderung memilih pekerjaan sebagai seorang PNS/TNI /POLRI, sedangkan di SMP Negri 39 Surabaya siswa lebih memilih sebagai Pengusaha. Ini berarti siswa di SMP Negeri 17 dan 39 Surabaya terjadi perbedaan keinginan tentang pekerjaan yang dicita-citakan.

Beberapa fenomena ditemuai setelah melakukan observasi awal yang mendukung maksud tersebut di atas antara lain : Status sosial ekonomi orang tua di SMP Negeri 17 ternyata kondisinya sangat bervariatif dan lebih besar yang kurang mampu dan cukup dibandingkan dengan yang ekonominya mapan /mampu. Sedangkan di SMP Negeri 39 jumlah kondisi orang tua yang mampu / mapan lebih besar dibandingkan dengan yang kondisinya kurang mampu dan cukup.

Melihat kondisi di atas, ternyata minat wirausaha siswa berbeda pada dua sekolah tersebut, adakah dipengaruhi oleh kondisi sosial ekonomi orang tua? Pendidikan yang diberikan keluarga, jenis pekerjaan yang mungkin akan memberikan pengaruh bagi anak/siswa.

Dari hal ini, maka minat wirausaha dalam penelitian dijadikan sebagai faktor yang adakah dipengaruhi oleh sosial ekonomi orang tua, literasi ekonomi, dan percaya diri?

Minat wirausaha menurut Subandono (2007) adalah kecenderungan hati dalam diri subjek untuk tertarik menciptakan suatu usaha yang kemudian mengorganisir, mengatur, menanggung risiko dan mengembangkan usaha yang diciptakannya tersebut. Itu berarti minat wirausaha berasal dari dalam diri seseorang untuk menciptakan sebuah bidang usaha. Santoso (1995) juga menyatakan bahwa minat wirausaha adalah gejala psikis untuk memusatkan perhatian dan berbuat sesuatu terhadapwirausaha itu dengan perasaan senang, karena membawa manfaat bagi dirinya maupun orang lain.

Berdasarkan definisi dan penjelasan diatas,maka yang dimaksud dengan minat wirausaha adalah keinginan, ketertarikan serta kesediaan untuk bekerja keras atau berkemauan keras dengan adanya pemusatan perhatian untuk berusaha memenuhi kebutuhan hidupnya tanpa merasa takut akan resiko yang akan dihadapi, senantiasa belajar dari kegagalan yang dialami, serta mengembangkan usaha yang diciptakannya.

Hal ini juga berarti minat berwirausaha adalah kecenderungan yang menetap dalam subyek untuk merasa tertarik pada bidang tertentu dan merasa senang berkecimpung dalam bidang itu terutama kemampuan kreatif dan inovatif yang dijadikan dasar, kiat dan sumber daya untuk mencari peluang menuju sukses. 
Untuk literasi ekonomi siswa di SMP Negeri 17 dan SMP Negeri 39 Surabaya masih kurang difahami, sehingga banyak dijumpai anak - anak yang seenaknya dalam membelanjakan keuangannya, jarang yang berpikir produktif, menggunakan uang seefisien mungkin, kurang menghargai dan menggunakan waktu untuk kegiataa-kegiatan yang positif.

Maftukhah (2007), menyatakan bahwa: pada umumnya anak yang berasal dari keluarga menengah ke atas lebih banyak mendapatkan pengarahan dan bimbingan yang baik dari orang tua mereka. Anak-anak yang berlatar belakang ekonomi rendah, kurang mendapat bimbingan dan pengarahan yang cukup dari orang tua mereka, karena orang tua lebih memusatkan perhatiannya pada bagaimana untuk memenuhi kebutuhan sehari-hari.

Keluarga memang mempunyai peranan penting, seperti yang dikatakan oleh Musthafa (2007). Keluarga merupakan lingkungan pertama yang memberikan wahana berkembangnya keterampilan literasi melalui berbagai cara diantaranya komunikasi timbal balik, fasilitasi media literer, penanaman nilai dalam aktivitas sehari-hari dan keterlibatan dalam pendidikan anak. Ini berrarti keluarga sangat dominan dalam membentuk karakter literasi pada anak.

Tidak kalah menariknya, Soemanto (1992) menyatakan orang tua atau lingkungan keluarga peletak dasar bagi persiapan anak - anak agar di masa yang akan datang menjadi perkerja yang efektif. Dalam mendidik anak, para orang tua harus mengajarkan anaknya memotivasi diri untuk bekerja keras, diberi kesempatan untuk bertanggung jawab atas apa yang dia lakukan.

Orang tua yang berwirausaha dalam bidang tertentu dapat menimbulkan minat anaknya untuk berwirausaha dalam bidang yang sama. Misalnya: orang tua yang memiliki usaha bengkel, kemudian anaknya membantu membongkar, mengecek, memeriksa. Sedangkan untuk status ekonomi, Menurut friedman (2004) faktor yang mempengaruhi status ekonomi seseorang yaitu: Pendidikan, pekerjaan, keadaan ekonomi, latar belakang budaya, dan pendapatan.

Pendidikan memang penting bagi seseorang untuk meningkatkan kemampuan termasuk memperoleh pekeraan dan penghasilan yang sepadan dengan pendidikannya.

Pendidikan merupakan usaha sadar untuk menyumbangkan kemampuan usaha manusia dalam rangka memajukan aktivitas. Pendidikan sebagai suatu aspek yang menyumbangkan sumber daya manusia yang dimaksudkan untuk meningkatkan pengetahuan dan kemampuan seseorang dalam berbagai kegiatan, juga diharapkan mampu membuka cara berpikir ekonomis dalam arti mampu mengembangkan potensi yang ada untuk memperoleh hasil semaksimal mungkin.

Menurut Driyarkara (1980) pendidikan adalah memanusiakan manusia. Pelaksanaan pendidikan berlangsung dalam keluarga sebagai pendidikan informal, di sekolah sebagai pendidikan formal, dan di masyarakat sebagai pendidikan nonformal serta berlangsung seumur hidup.

Masyarakat yang mempunyai tingkat sosial ekonomi yang rendah cenderung memiliki tingkat pendidikan yang rendah pula. Masyarakat masih kurang memahami akan pentingnya pendidikan. Masyarakat masih beranggapan bahwa pendidikan bukan merupakan jaminan bisa hidup sejahtera, jauh dari kemiskinan. Dengan anggapan bahwa sekolah hanya membuang waktu dan biaya saja. 
Pendidikan dasar saja belum cukup untuk menunjang pembangunan yang sedang berlangsung, guna menuju masyarakat adil makmur dan sejahtera. Masih banyak masyarakat yang tidak berhasil menyelesaikan pendidikan dasar sampai dengan selesai, apa lagi sampai sarjana dan seterusnya.

Sejalan hal di atas, pendidikan memang penting dalam meberikan literasi ekonomi kepada anak, pandangan Mathews (1999) bahwa literasi ekonomi adalah sebagai kemampuan individu untuk mengenali dan menggunakan konsepkonsep ekonomi dan cara berpikir ekonomi untuk memperbaiki dan mendapatkan kesejahteraan.

Di samping kemampuan berliterasi ekonomi siswa sebaiknya juga memiliki percaya diri. Menurut Suryana (2008) kepercayaan diri adalah sikap dan keyakinan seseorang dalam melaksanakan dan menyelesaikan tugastugasnya.

Siswa SMP Negeri 17 dan SMP Negeri 39 Surabaya kurang percaya atas kemampuan yang dimiliki, mudah putus asa dalam menghadapi permasalahan yang dihadapi, kurang berani dalam menyampaikan pendapat dalam kegiatan, termasuk menyampaikan kesulitan tiap-tiap pelajaran kepada guru pengajarnya.

Sejalan hal di atas menurut Lauster (2002) percaya diri (self confidence) merupakan suatu sikap/keyakinan atas kemampuan diri sendiri sehingga dalam tindakan - tindakannya tidak terlalu cemas, merasa bebas untuk melakukan hal-hal yang sesuai dengan keinginandan tanggung jawab atas perbuatannya, sopan dan berinteraksi dengan orang lain, memiliki dorongan prestasi serta dapat mengenal kelebihan dan kekurangan diri sendiri.

Diperkuat oleh Siti Rochmah Maulida dan Dini Rama Dhani (2012) dalam penelitiannya menyimpulkan bahwa, kepercayaan diri, dukungan orang tua memberikan pengaruh signifikan terhadap motivasi berwirausaha.

Hal serupa juga disampaikan oleh Arista(2012) dalam penelitiannya menyimpulkan terdapat pengaruh yang signifikan antara efikasi diri terhadap minat wirausaha siswa.

Kurangnya percaya diri pada siswa akan berpengaruh rendahnya pada individu untuk memiliki gagasan, karsa, inisiatif, kreativitas, keberanian, ketekunan, semangat kerja keras, dan kegairahan berkarya, (Suryana, 2008).

Sedangkan Literasi ekonomi perlu ditanamkan dan ditumbuhkan sejak dini sebab kemampuan literasi ekonomi tidak timbul dengan sendirinya tetapi sangat dipengaruhi oleh orang lain, termasuk keteladanan orang tua.

Menurut Matsuura (2006) bahwa literasi bukan hanya saja menyangkut keahlian berpikir dan membaca melainkan menyangkut proses pembelajaran (learning) dan keahlian hidup (life skill) yang akan digunakan manusia, komunitas ataupun suatu bangsa untuk bertahan dan secara berkelanjutan mengalami perubahan. Dengan kata lain, tanpa literasi maka suatu bangsa, komunitas ataupun manusia akan kesulitan memastikan untuk tetap bertahan hidup selayaknya sebagai manusia.

Tidak jauh berbeda, menurut Collins dan Thesaurus (2006) Bahwa literasi berarti kemampuan membaca, menulis, pendidikan, pembelajaran dan pengetahuan. Sumber lain, the new American webster handy college dictionarybahwa literasi diartikan sebagai membaca dan ilmu pengetahuan. Selain itu, literasi juga berkaitan dengan pembelajaran. 
Makna kemampuan (ability) mengindikasikan bahwa pemahamanliterasiekonomi dihasilkan melalui proses belajar yang berkesinambungan sehingga dapat dikatakanbahwa literasi keuangan merupakan bagian juga dari literasi ekonomi.

Disampaikan pula oleh Wulandari (2011) bahwa literasi ekonomi adalah ketrampilan hidup (life skill) yang harus dimiliki oleh siapa saja untuk membuat keputusan ekonomi yang tepat. Oleh karena itu, literasi ekonomi dapat diaplikasikan untuk konteks individu maupun rumah tangga.

Literasi ekonomi merupakan alat yang berguna untuk merubah perilaku dari tidak cerdas menjadi cerdas. Membuatkeputusan ekonomiyang cerdas adalah suatu pilihan, dan pilihan ini memerlukan upaya. Individu juga perlu memahami syarat-syarat yang tepat guna membuat keputusan ekonomi seharihari. Terkait upaya dan persyaratan tersebut maka literasi ekonomi menjadi suatu pilihan yang sebaiknya dimiliki oleh seseorang. Hanya saja pada kenyataannya tidak semua orang memiliki literasi ekonomi yang memadai guna membuat keputusan yang cerdas.

Tujuan penelitian kami adalah: (a).Untuk menganalisis seberapa besar pengaruh sosial ekonomi orang tua terhadap minat wirausaha siswa? (b). Untuk menganalisis seberapa besar pengaruh literasi ekonomi terhadap minat wirausaha siswa? (c). Untuk menganalisis seberapa besar pengaruh percaya diri terhadap minat wirausaha siswa? (d). Untuk menganalisis seberapa besar pengaruh sosial ekonomi orang tua, literasi ekonomi, percaya diri secara bersama - sama/ simultan terhadap minat wirausaha siswa?

\section{METODE PENELITIAN}

Berkaitan dengan paparan di atas, maka dalam desain penelitian ini variabel bebas pertama $\left(\mathrm{X}_{1}\right)$ adalah Status Sosial Ekonomi, variabel bebas kedua $\left(\mathrm{X}_{2}\right)$ adalah Literasi Ekonomi. Dan variabel bebas ketiga $\left(\mathrm{X}_{3}\right)$ adalah Percaya diri. Selanjutnya penelitian ini mencoba mencari pengaruh variabel $\mathrm{X}_{1}$ terhadap variabel $\mathrm{Y}$, pengaruh variabel $\mathrm{X}_{2}$ terhadap variabel $\mathrm{Y}$, variabei $\mathrm{X}_{3}$ terhadap variabel $\mathrm{Y}$ dan pengaruh variabel $\mathrm{X}_{1}, \mathrm{X}_{2}, \mathrm{X}_{3}$ secara bersama - sama terhadap variabel Y.

Populasi adalah semua siswa SMP Negeri kelas VIII di Kecamatan Tenggilis Mejoyo Surabaya, yang terdiri dari sepuluh kelas di SMP Negeri 17 dan delapan kelas di SMP Negeri 39, sehingga total jumlah populasi dalam penelitian ini adalah 18 kelas dengan jumlah toatal siswa 686 orang,

Penentuan sampel ditentukan dengan menggunakan teknik sampel random sampling dan rumus yang digunakan adalah pendapat Slovin dalam Sukardi(2009) dengan tingkat toleransi terjadinya galat 0.05 atau 5\% dan tingkat kepercayaan 0.95 atau $95 \%$, dapat dihitung dengan rumus berikut; $\mathrm{n}=\mathrm{N} /\left(1+\mathrm{Ne}^{\wedge} 2\right)$,

Dengan rumusSlovin dalam Sukardi (2009)maka perhitungannya adalah sebagai berikut;

$\mathrm{n}=\mathrm{N} /\left(1+\mathrm{Ne}^{\wedge} 2\right)$ Jumlah sampel $=686:(1+686 \times 0.05 \times 0.05)=253$

Karena jumlah sampelnya 253 orang/siswa, maka dalam penyebaran angket di tiap kelas akan memperoleh $253: 18=14$ (siswa), kecuali pada kelas 8-G dan 8-H di SMP Negeri 39 berjumlah 15 anak. 
Teknik yang digunakan untuk pengumpulan data dalam penelitian ini dengan menyebarkan daftar pertanyaan / angket tertutup. Peneliti mengembangkan angket dengan pilihan jawaban yang sudah ditentukan sehingga responden tinggal memilih alternatif jawaban yang sesuai dengan kondisi yang dialami atau dirasakan. Metode ini digunakan untuk memperoleh data primer, yaitu data yang diperoleh langsung dari para responden. Teknik analisis dalam penelitian ini menggunakan Regresi linier berganda guna mengetahui pengaruh variabel bebas secara bersama - sama terhadap variabel terikat. Persamaannya adalah:

$$
\mathrm{Y}=\mathrm{a}+\mathrm{b}_{1} \mathrm{X}_{1}+\mathrm{b}_{2} \mathrm{X}_{2}+\mathrm{b}_{3} \mathrm{X}_{3}+\mathrm{e}
$$

Pengujian hipotesis dalam penelitian ini terdiri dari uji parsial (t-test) dan uji simultan(f- test). Uji t (uji koefisien regresi secara parsial) Uji t ini bertujuan untuk mengetahui signifikasi masing - masing variabel bebas (X) terhadap variabel terikat(Y). Dalam penelitian ini uji t digunakan untuk menguji signifikasi koefisien regresi atas variabel $\mathrm{X}$ terhadap variabel $\mathrm{Y}$ parsial dan variabel $\mathrm{X}$ secara bersama - sama terhadap variabel Y. Rumus yang digunakan adalah: $t=[r \sqrt{n}-$ $2]:\left[\sqrt{ } 1-\mathrm{r}^{2}\right]$

Hasil uji t yang diperoleh kemudian di asumsikan kepada hipotesia yang ada. Menggunakan taraf kesalahan sebesar $5 \%$ dengan ketentuan : Jika $r>0.05$, maka hipotesis nol (Ho) dterima dan hipotesis kerja (Ha) ditolak, menunjukkan tidak adanya pengaruh yang signifikan Status Sosial Ekonomi Orang Tua, Literasi Ekonomi. Percaya Diri terhadap Minat Wirausaha secara parsial. Jika $r<0.05$, maka hipotesis nol (Ho) ditolak dan hipotesis kerja (Ha) diterima, menunjukkan adanya pengaruh yang signifikan Status Sosial Ekonomi Orang Tua, Literasi Ekonomi. Percaya Diri terhadap Minat Wirausaha secara parsial.

Uji F (uji koefisien regresi secara simultan) Uji $F$ ini bertujuan untuk mengetahui signifikasi semua variabel bebas terhadap variabel terikat. Dalam penelitian ini uji $\mathrm{F}$ digunakan menguji signifikasi koefisien regresi atas variabel $\mathrm{X}$ dan variabel $\mathrm{X}$ secara bersama - sama terhadap variabel $\mathrm{Y}$. Rumus yang digunakan adalah:

$$
\mathrm{F}=\left[\mathrm{R}^{2} /(\mathrm{K}-1)\right]:\left[\left(1-\mathrm{R}^{2}\right) /(\mathrm{N}-\mathrm{K})\right]
$$

Hasil uji $\mathrm{F}$ yang diperoleh kemudian di asumsikan kepada hipotesis yang ada. Menggunakan taraf kesalahan sebesar $5 \%$ dengan ketentuan : Jika $\mathrm{F}<0.05$, maka koefisien korelasi berganda yang diuji adalah signifikasi, menunjukkan adanya pengaruh yang signifikan Status Sosial Ekonomi Orang Tua, Literasi Ekonomi. Percaya Diri terhadap Minat Wirausaha secara simultan.

\section{HASIL PENELITIAN DAN PEMBAHASAN}

Bagian analisis ini membahas mengenai bentuk sebaran jawaban responden terhadap seluruh variabel beserta instrumen penelitian yang diukur mengenai status sosial ekonomi orang tua $\left(\mathrm{X}_{1}\right)$, literasi ekonomi $\left(\mathrm{X}_{2}\right)$ dan percaya diri $\left(\mathrm{X}_{3}\right)$, serta minat wirausaha siswa (Y) SMP Negeri di Kecamatan Tenggilis Wejoyo, Surabaya. Sebelum deskripsi lebih lanjut, selanjutnya dirumuskan penjelasan 
mengenai interval kelas masing-masing sebagai standar ukur penjelasan dalam deskripsi variabel yaitu dengan menggunakan rumus sebagai berikut(Riduwan, 2009):

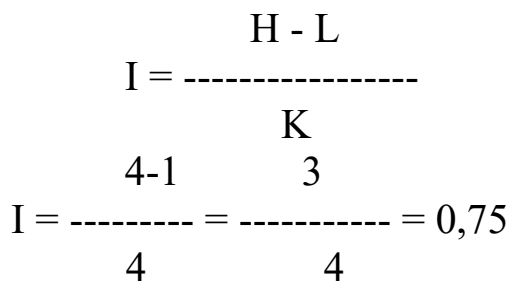

Dengan diketahui interval kelas yaitu 0,75 kemudian disusun kriteria penilaian rata-rata jawaban responden dan selanjutnya distribusi dari masingmasing kategori tanggapan responden untuk masing-masing variabel adalah sebagai berikut:

\section{Deskripsi Variabel Status Sosial Ekonomi Orang Tua $\left(\mathbf{X}_{1}\right)$}

Dalam variabel status sosial ekonomi orang tua $\left(\mathrm{X}_{1}\right)$ terdiri dari 3 indikator yang setiap indikatornya mempunyai beberapa item pernyataan. Berikut ini adalah deskripsi frekuensi dari setiap indikator status sosial ekonomi orang tua $\left(\mathrm{X}_{1}\right)$

Deskripsi frekuensi variabel status sosial ekonomi orang tua menunjukkan bahwa, siswa memiliki status sosial ekonomi orang tua yang tinggi, baik itu dilihat dari tingkat pekerjaan, pendidikan, maupun tingkat penghasilan mereka.

Jika dilihat dari nilai rata-rata keseluruhan deskripsi variabel status sosial ekonomi orang tua yaitu sebesar 3,96\% serta masuk dalam kategori tinggi, sedangkan untuk indikator paling rendah yaitu sebesar 3,62 adalah indikator terhadap penghasilan ekonomi orang tua, sedangkan yang tertinggi yaitu sebesar 3,77 yaitu indikator tingkat pendidikan orang tua siswa. Sedangkan secara keseluruhan nilai rata-rata variabel status sosial ekonomi orang tua yaitu sebesar 3,69 termasuk kategori sangat tinggi, hal ini berarti para siswa SMP Negeri di Kecamatan Tenggilis Wejoyo Surabaya, memiliki pengaruh status sosial ekonomi orang tua yang tinggi. Yang nantinya dapat mendukung hasrat, keinginan terutama minat wirausaha siswa dalam diri mereka kedepannya.

Deskripsi Variabel Literasi Ekonomi $\left(\mathrm{X}_{2}\right)$, Variabel literasi ekonomi terdiri dari 6 indikator. Berikut ini merupakan deskripsi frekuensi dari indikatorindikator sesuai dengan lampiran yang ada.

Deskripsi frekuensi variabel literasi ekonomi menunjukkan bahwa, siswa memiliki pemahaman terhadap literasi ekonomi yang sangat tinggi.Jika dilihat dari nilai rata-rata keseluruhan variabel literasi ekonomi yaitu sebesar 3,59 dan masuk dalam kategori sangat tinggi, hal ini berarti siswa paham terhadap kebutuhan, kelangkaan, prinsip ekonomi, motif ekonomi, perilaku siswa dan juga memiliki keinginan dalam menabung. secara keseluruhan, dapat disimpulkan bahwa untuk indikator paling rendah yaitu sebesar 3,37 adalah indikator pemahaman siswa terhadap kelangkaan, sedangkan yang tertinggi yaitu sebesar 3,74 yaitu indikator pemahaman terhadap prinsip-prinsip ekonomi. Sedangkan secara keseluruhan nilai rata-rata variabel literasi ekonomi yaitu sebesar 3,59 termasuk kategori sangat tinggi, maka dari itu dapat diambil kesimpulan bahwa 
pemahaman literasi ekonomi yang siswa miliki di SMP Negeri se-kecamatan Tenggilis Mejoyo Surabaya sangat baik.

Deskripsi Variabel Percaya Diri $\left(\mathrm{X}_{3}\right)$, Variabel percaya diri terdiri dari 7 indikator. Berikut ini merupakan deskripsi frekuensi dari masing-masing indikator sesuai dengan lampiran yang ada.

Deskripsi frekuensi variabel percaya diri menunjukkan bahwa, siswa di SMP Negeri di kecamatan Tenggilis Mejoyo Surabaya memiliki kepercayaan diri yang baik. Sedangkan dilihat dari nilai rata-rata keseluruhan variabel percaya diri yaitu sebesar 3,64 dan masuk dalam kategori sangat tinggi, Secara keseluruhan, dapat disimpulkan bahwa untuk indikator paling rendah yaitu sebesar 3,55 adalah indikator memiliki tanggung jawab dengan tugas-tugasnya, sedangkan yang tertinggi yaitu sebesar 3,74 yaitu indikator berani menyampaikan pendapat. Sedangkan secara keseluruhan nilai rata-rata variabel percaya diri yaitu sebesar 3,64 termasuk kategori sangat tinggi.

Deskripsi Variabel Minat Wirausaha Siswa (Y)Variabel minat wirausaha siswa terdiri dari 2 indikator, dengan beberapa sub indikator Berikut ini merupakan deskripsi frekuensi dari masing-masing indikator:Deskripsi frekuensi variabel minat wirausaha menunjukkan bahwa, siswa memiliki minat wirausaha yang tinggi, sedangkan dilihat dari nilai rata-rata keseluruhan variabel minat wirausaha yaitu sebesar 3,69 dan masuk dalam kategori sangat tinggi, hal ini berarti siswa berkeinginan dan memiliki rasa senang dalam menekuni aktivitas yaitu dalam hal kewirausahaan.

Uji Asumsi Klasik yang dilakukan dalam penelitian ini menggunakan uji normalitas, uji linieritas, uji heterokedastisitas, dan uji multikolinieritas. Setelah melalui tahapan uji asumsi klasik dengan memenuhi syarat maka untuk selanjutnya dilakukan uji hipotesis dengan hasil sebagai berikut:

Tabel 1. Hasil Uji t

\begin{tabular}{|c|c|c|c|c|c|c|}
\hline \multirow{2}{*}{\multicolumn{2}{|c|}{ Model }} & \multicolumn{2}{|c|}{ Unstandardized Coefficients } & \multirow{2}{*}{$\begin{array}{c}\text { Standardized } \\
\text { Coefficients } \\
\text { Beta }\end{array}$} & \multirow[b]{2}{*}{$\mathrm{t}$} & \multirow[b]{2}{*}{ Sig. } \\
\hline & & $\mathrm{B}$ & Std. Error & & & \\
\hline \multirow[t]{5}{*}{1} & (Constant) & 11.845 & 1.282 & & 9.237 & .000 \\
\hline & Status Sosial & & & & & \\
\hline & Ekonomi Orang Tua & .526 & .044 & .105 & 12.046 & .000 \\
\hline & Literasi Ekonomi & .147 & .061 & .191 & 2.388 & .018 \\
\hline & Percaya Diri & .135 & .032 & .363 & 4.185 & .000 \\
\hline
\end{tabular}

a. Dependent Variable: Minat Wirausaha

Analisis Regresi Linear Berganda, Hasil pengolahan data dengan metode regresi linear berganda, dengan Persamaan sebagai berikut:Y $=11.845+0,526 \mathrm{X} 1$ $+0,147 \mathrm{X} 2+0,135 \mathrm{X} 3+$ ei. Dari persamaan regresi tersebut tampak bahwa :Konstanta (a) yang dihasilkan sebesar 11.845 hal ini menunjukkan bahwa besarnya minat wirausaha adalah 11.845 jika variabel status sosial ekonomi orang tua, literasi ekonomi, dan percaya diri adalah tetap. 
Koefisien regresi pada variabel status sosial ekonomi orang tua yang dihasilkan adalah positif yaitu sebesar 0,526 hal ini menunjukkan bahwa jika status sosial ekonomi orang tua naik satu satuan maka minat wirausaha akan naik sebesar 0,526 satuan dengan asumsi variabel literasi ekonomi dan percaya diri adalah konstan.

Koefisien regresi pada variabel literasi ekonomi yang dihasilkan adalah positif yaitu sebesar 0,147 hal ini menunjukkan bahwa jika literasi ekonomi naik satu satuan maka minat wirausaha akan naik sebesar 0,147 satuan dengan asumsi variabel sosial ekonomi orang tua dan percaya diri adalah konstan.

Koefisien regresi pada variabel percaya diri yang dihasilkan adalah positif yaitu sebesar 0,135 hal ini menunjukkan bahwa setiap perubahan variabel percaya diri akan berpengaruh negatif pada minat wirausaha. Nilai koefisien regresi negatif menunjukkan pengaruh yang timbul tidak searah, dimana naiknya variabel percaya diri sebesar satu satuan maka minat wirausaha akan turun sebesar 0,135 satuan dengan asumsi variabel status sosial ekonomi orang tua dan literasi ekonomi adalah konstan.

Tabel 2 Hasil Uji F

\begin{tabular}{|ll|r|r|r|r|r|}
\hline \multicolumn{1}{|l|}{ Model } & & Sum of Squares & \multicolumn{1}{c|}{$\mathrm{df}$} & Mean Square & \multicolumn{1}{c|}{$\mathrm{F}$} & \multicolumn{1}{c|}{ Sig. } \\
\hline 1 & Regression & 146.665 & 3 & 48.888 & 53.240 & $.000^{\mathrm{b}}$ \\
& Residual & 228.647 & 249 & .918 & & \\
& Total & 375.312 & 252 & & & \\
\hline
\end{tabular}

a. Dependent Variable: Minat Wirausaha

b. Predictors: (Constant), Percaya Diri, Status Sosial Ekonomi Orang Tua, Literasi Ekonomi

Tabel 3. Hasil Uji Koefisien determinasi

\begin{tabular}{|l|r|r|r|r|}
\hline Model & $\mathrm{R}$ & $\mathrm{R}$ Square & \multicolumn{1}{c|}{$\begin{array}{c}\text { Adjusted R } \\
\text { Square }\end{array}$} & $\begin{array}{l}\text { Std. Error of the } \\
\text { Estimate }\end{array}$ \\
\hline 1 & $.625^{\mathrm{a}}$ & .391 & .383 & .958 \\
\hline
\end{tabular}

a. Predictors: (Constant), Percaya Diri, Status Sosial Ekonomi Orang

Tua, Literasi Ekonomi

Uji F digunakan untuk menguji pengaruh variabel status sosial ekonomi keluarga, literasi ekonomi, dan percaya diri terhadap minat wirausaha. Hasil uji $\mathrm{F}$ menjelaskan bahwa status sosial ekonomi keluarga, literasi ekonomi, dan percaya diri secara simultan atau bersama-sama berpengaruh signifikan pada minat berwirausaha, hal ini terlihat dari nilai Fhitung yang dihasilkan sebesar 53,240 lebih besar dari $\mathrm{F}$ tabel sebesar 2,65 dengan nilai signifikansi $\mathrm{p}=0,000$ lebih kecil dari $5 \%$.

Nilai Koefisien Determinasi Besarnya pengaruh variabel status sosial ekonomi keluarga, literasi ekonomi, dan percaya diri secara simultan terhadap minat wirausaha siswa dapat dilihat dari koefisien determinasi ( $R$-square) yaitu sebesar 0,391 menunjukkan bahwa minat wirausaha siswa dipengaruhi oleh status sosial ekonomi keluarga, literasi ekonomi, dan percaya diri sebesar 39,1\% 
sedangkan $60,9 \%$ dipengaruhi oleh faktor-faktor lain selain variabel dalam penelitian ini.

Uji t dan Nilai $r$ parsial, Uji t digunakan untuk mengetahui pengaruh status sosial ekonomi keluarga, literasi ekonomi, dan percaya diri secara parsial pada minat wirausaha. Adapun hasil uji diperoleh sebagai berikut :

Nilai t-hitung pada variabel status sosial ekonomi orang tua $\left(\mathrm{X}_{1}\right)$ sebesar 12,047 dengan tingkat signifikan kurang dari pada 5\% yaitu 0.000 . Artinya status sosial ekonomi orang tua $\left(\mathrm{X}_{1}\right)$ secara parsial berpengaruh signifikan pada minat wirausaha siswa (Y).

Nilai t-hitung pada variabel persepsi siswa $\left(\mathrm{X}_{2}\right)$ sebesar 7.231 dengan tingkat signifikan kurang dari $5 \%$ yaitu 0.000 . Artinya persepsi siswa $\left(\mathrm{X}_{2}\right)$ secara parsial berpengaruh signifikan pada hasil belajar siswa (Y).

Hasil uji hipotesis, Untuk mengetahui hipotesis yang diajukan oleh penulis terjawab atau tidak dalam penelitian ini maka berdasarkan hasil pengolahan data diatas disimpulkan sebagai berikut :

Hipotesis 1 yaitu ada pengaruh signifikan status sosial ekonomi orang tua terhadap minat wirausaha siswa" terjawab dari hasil t-hitung sebesar 12,047 dengan tingkat signifikan kurang dari $5 \%$.

Hipotesis ke 2 ada pengaruh signifikan literasi ekonomi terhadap minat wirausaha siswa terjawab dari hasil nilai t-hitung sebesar 2,388 dengan tingkat signifikan kurang dari $5 \%$ yaitu 0,018 Hal ini berarti bahwa literasi ekonomi secara parsial berpengaruh signifikan terhadap minat wirausaha siswa.

Hipotesis 3 yaitu ada pengaruh signifikan percaya diri terhadap minat wirausaha siswa di SMP Negeri kecamatan Tenggilis Mejoyo Surabaya." terjawab dari hasil nilai t-hitung sebesar -4.185 dengan tingkat signifikan kurang dari $5 \%$ yaitu 0,000 .

Hipotesis 4 yaitu "Diduga ada pengaruh signifikan sosial ekonomi orang tua, literasi ekonomi, dan percaya diri secara bersama - sama terhadap minat wirausaha siswa, terjawab dari hasil uji f-hitung yaitu 53,240 dengan tingkat signifikan kurang dari 5\% yaitu 0,000. Hal ini menunjukkan bahwa status sosial ekonomi orang tua, literasi ekonomi, dan percaya diri secara bersama- sama berpengaruh signifikan terhadap minat wirausaha siswa di SMP Negeri di kecamatan Tenggilis Mejoyo Surabaya.

\section{Pengaruh Status Sosial Ekonomi Orang Tua Terhadap Minat Wirausaha Siswa.}

Berdasarkan hasil analisis menunjukkan bahwa status sosial ekonomi orang tua berpengaruh signifikan terhadap minat wirausaha siswa SMP Negeri di Kecamatan Tenggilis Mejoyo Surabaya. Hasil ini sesuai dengan temuan penelitian orang lain, di mana minat wirausaha siswa akan meningkat apabila status sosial ekonomi orang tua semakin tinggi. Seperti yang diungkapkan oleh Soetjiningsih (2004) bahwa status sosial ekonomi merupakan kedudukan atau posisi seseorang dalam masyarakat, juga merupakan keadaan seseorang atau suatu masyarakat yang ditinjau dari segi tingkat pendidikan, pendapatandan pekerjaan, jika hal tersebut semakin mapan akan meningkatkan minat wirausaha. Teori tersebut juga sejalan dengan yang diungkapkan oleh Schiffman \& Kanuk (2008) bahwa pada umumnya semakin tinggi tingkat pendidikan seseorang maka semakin besar kemungkinan orang untuk bergaji tinggi (berpenghasilan tinggi) dan mempunyai 
kedudukan yang dikagumi serta dihormati. Sehingga dapat meningkatkan minat wirausaha, maka dapat disimpulkan bahwa dengan status sosial yang tinggi, maka seseorang memiliki minat yang tinggi untuk berwirausaha.

Hasil penelitian ini juga didukung oleh penelitian yang dilakukan oleh Suhartini (2011) yang mengungkapkan bahwa status sosial ekonomi orang tua berpengaruh signifikan terhadap minat berwirausaha.

Status sosial ekonomi orang tua berpengaruh signifikan terhadap minat wirausaha siswa di SMP Negeri di Kecamatan Tenggilis Mejoyo Surabaya. Didukung oleh temuan pada variabel status sosial ekonomi orang tua dalam penelitian ini yang lebih dominan didukung oleh indikator "Tingkat pendidikan orang tua". Hal ini dapat ditunjukkan dari temuan bahwa rata-rata tingkat pendidikan yang dimiliki orang tua siswa di SMP 39 dan SMP 17 Surabaya ada pada perguruan tinggi.

Temuan berikutnya pada variabel status sosial ekonomi orang tua yaitu pada indikator "Tingkat penghasilan orang tua siswa" yang menunjukkan hasil paling rendah dibandingkan variabel yang lainnya. Hal tersebut ditunjukkan dari hasil temuan bahwa walaupun sebelumnya seperti yang telah dijelaskan bahwa tingkat pendidikan para orang tua siswa tinggi, akan tetapi tidak semua orang tua dari siswa bekerja keduanya sehingga terjadi perbedaan dalam hal penghasilan yang mereka miliki dan hal tersebut juga berpengaruh pada dukungan terhadap minat wirausaha yang mereka miliki.

Dari pembahasan tersebut menunjukkan bahwa status sosial ekonomi yang dimiliki orang tua siswa dapat juga dijadikan sebagai salah satu faktor pendukung bagi minat wirausaha yang dimiliki oleh siswa. Sehingga dapat disimpulkan bahwa dalam penelitian ini status sosial ekonomi orang tua memiliki pengaruh yang positif terhadap minat wirausaha siswa di SMP Negeri di Kecamatan Tenggilis Mejoyo Surabaya.

\section{Pengaruh Literasi Ekonomi Terhadap Minat Wirausaha Siswa}

Berdasarkan hasil analisis menunjukkan bahwa literasi ekonomi berpengaruh signifikan dan berdampak positif terhadap minat wirausaha siswa SMP Negeri di Kecamatan Tenggilis Mejoyo Surabaya. Hasil tersebut mempunyai makna bahwa minat wirausaha akan meningkat apabila literasi ekonomi siswa SMP Negeri di kecamatan Tenggilis Mejoyo Surabaya semakin ditingkatkan. Sehingga semakin baik literasi ekonomi yang dimiliki siswa, semakin baik pula minat wirausaha siswa.

Hasil penelitian ini juga didukung teori sebelumnya, yang dikemukakan oleh Mathews (1999) bahwa literasi ekonomi merupakan kemampuan individu untuk mengenali dan menggunakan konsep-konsep ekonomi serta cara berpikir ekonomi untuk selalu memperbaiki dan mendapatkan kesejahteraannya. Dan juga didukung dengan yang diungkapkan oleh Kurt (2011) bahwa salah satu bidang keaksaraan yang paling penting terjadi sebagai syarat dan hasil dari era informasi adalah literasi ekonomi. Karena dengan adanya kesadaran serta pemahaman tentang ekonomi yang baik, hal tersebut dapat membuat orang bertahan hidup serta mengembangkan berbagai macam usaha di tengah sulitnya kehidupan ekonomi sehingga diharapkan nantinya dapat meningkatkan tingkat kreatifitas siswa dan pada akhirnya juga dapat mengembangkan minat wirausaha yang dimiliki siswa SMP Negeri di Kecamatan Tenggilis Mejoyo Surabaya. 
Selain teori yang telah disebutkan diatas, penelitian ini juga sejalan dengan penelitian sebelumnya, yang dilakukan oleh Suhartini ( 2011) bahwa terdapat kontribusi tinggi yang diberikan oleh orang tua untuk anak-anak mereka tentang literasi ekonomi. Hal yang serupa diungkapkan oleh Wulandari (2011) bahwa literasi ekonomi merupakan keterampilan hidup yang harus selalu dimiliki sehingga nantinya dapat dijadikan pembuat keputusan ekonomi yang tepat.

Literasi ekonomi sendiri berpengaruh signifikan terhadap minat wirausaha siswa SMP Negeri di Kecamatan Tenggilis Mejoyo Surabaya, didukung oleh temuan pada indikator yang lebih dominan yaitu "Pemahaman terhadap prinsipprinsip ekonomi”. Hal ini terbukti dari nilai-nilai yang dimiliki pada saat pembelajaran berlangsung.

Sedangkan temuan berikutnya pada variabel literasi ekonomi yaitu pada indikator "Pemahaman siswa terhadap kelangkaan", yang menunjukkan hasil paling rendah dibandingkan indikator yang lainnya, tetapi walaupun demekianmasih memberikan pengaruh signifikan terhadap minar wirausaha siswa.

Dari seluruh pembahasan diatas dapat disimpulkan bahwa pemahaman literasi ekonomi yang dimiliki oleh siswa SMP Negeri di kecamatan Tenggilis Mejoyo Surabaya, dapat meningkatkan minat wirausaha.

\section{Pengaruh Percaya Diri Terhadap Minat Wirausaha Siswa}

Berdasarkan hasil analisis menunjukkan bahwa percaya diri berpengaruh signifikan, semakin tinggi tingkat percaya diri siswa semakin tinggi minat wirausaha mereka, walaupun demikian percaya diri siswa masih harus ditingkatkan lagi agar minat wirausaha mereka tumbuh dan berkembang lebih baik.

Hasil penelitian ini didukung juga oleh teori sebelumnya, yang dikemukakan oleh Syaifullah (2010) bahwa percaya diri dibagi menjadi dua yaitu batin, yang merupakan dimana kepercayaan diri tersebut memberikan perasaan dan anggapan bahwa individu dalam keadaan baik, sedangkan lahiriah merupakan suatu sifat keyakinan seseorang atas segala yang ada pada dirinya yang berkenaan dengan hal yang tampak. Dari kepercayaan diri yang dimiliki memberikan pengaruh positip terhadap minat wirausaha seseorang.

Selain teori tersebut, penelitian ini juga sejalan dengan penelitian sebelumnya, yang dilakukan oleh Bustan 2014) yang menyatakan bahwa terhadap hubungan yang positif antara kepercayaan diri yang dimiliki dengan minat wirausaha.

Meningkatnya kepercayaan diri siswa memberikan dukungan terhadap tumbuh dan berkembangnya minat wirausaha. Minat wirausaha akan berkembang lebih baik seiring dengan meningkat kepercayaan diri siswa.

Tingkat kepercayaan diri sendiri berpengaruh positif terhadap minat wirausaha siswa SMP Negeri di kecamatan Tenggilis Mejoyo Surabaya, hal tersebut didukung oleh temuan pada indikator yang lebih dominan yaitu "berani menyampaikan pendapat". Hal ini dapat ditunjukkan dengan keberanian yang tinggi dalam mengutarakan pendapat mereka, seperti pada saat siswa mempresentasikan hasil diskusi di depan kelas. Siswa terlihat aktif, pertanyaan, jawaban, dan sanggahan silih berganti dari beberapa kelompok diskusi saat pembelajaran sedang berlangsung. Pemikiran baru, ide kreatif dan keberanian dalam menyampaikan pendapat membuat suasana diskusi lebih hidup. 
Temuan berikutnya pada variabel percaya diri yaitu pada indikator "memiliki tanggung jawab dengan tugas-tugasnya" yang menunjukkan hasil paling rendah dibandingkan variabel yang lainnya. Hal tersebut ditunjukkan dari hasil temuan bahwa walaupun para siswa memiliki semangat yang tinggi dalam hal penyampaian pendapat akan tetapi dalam hal memiliki tanggung jawab dengan tugas-tugas yang diberikan seringkali masih kurang, hal tersebut dapat dilihat dari sejumlah siswa yang tidak mengumpulkan tugas yang diberikan.

Meskipun demikian dapat disimpulkan bahwa dalam penelitian ini tingkat percaya diri memiliki pengaruh positif terhadap minat wirausaha siswa SMP Negeri di Kecamatan Tenggilis Mejoyo Surabaya.

\section{Pengaruh Sosial Ekonomi Orang Tua, Literasi Ekonomi, Dan Percaya Diri Terhadap Minat Wirausaha Siswa.}

Berdasarkan hasil analisis untuk hipotesis ke empat yaitu "Diduga ada pengaruh signifikan sosial ekonomi orang tua, literasi ekonomi, dan percaya diri secara bersama - sama terhadap minat wirausaha siswa di SMP Negeri di Kecamatan Tenggilis Mejoyo Surabaya" menunjukkan bahwa ketiga variabel tersebut berpengaruh signifikan terhadap minat wirausaha. Hasil tersebut mempunyai makna bahwa minat wirausaha siswa akan semakin meningkat, apabila ketiga variabel tersebut mengalami peningkatan secara positif.

Selain telah disebutkan diatas, penelitian ini juga sejalan dengan penelitian sebelumnya, yang dilakukan oleh Kumari (2012), tentang pengaruh positif pengetahuan ekonomi/ekonomi literasi dan percaya diri terhadap kewirausahaan. Dan juga yang diungkapkan oleh Arum (2013) tentang pengaruh positip orang tua dan self efficacy terhadap kewirausahaan.

Literasi ekonomi sendiri berpengaruh signifikan terhadap minat wirausaha siswa di SMP Negeri di kecamatan Tenggilis Mejoyo Surabaya, didukung oleh temuan pada indikator yang lebih dominan yaitu pemahaman terhadap prinsip prinsip ekonomi, Hal ini dapat ditunjukkan dari temuan bahwa siswa- siswa sangat baik dalam pemahaman terhadap materi tersebut.

Temuan berikutnya dari variabel literasi ekonomi yaitu pada indikator pemahaman terhadap kelangkaan menunjukkan hasil paling rendah dibandingkan variabel lainnya. Hal ini terlihat dari hasil temuan bahwa anak - anak dalam memahami kelangkaan dan pengaruhnya terhadap harga sangat kurang dan memerlukan contoh-contoh kongkrit.

Meskipun demikian dari indikator literasi ekonomi secara keseluruhan mudah dipahami oleh siswa, lebih penting lagi siswa menerapkannya dalam kehidupan sehari - hari, seperti pandai berdagang, mengatur pengeluaran uang saku dan membuat urutan daftar kebutuhan.

Dari pembahasan di atas menunjukkan bahwa Status sosial ekonomi orang tua, Literasi ekonomi dan percaya diri berpengaruh signifikan terhadap minat wirausaha siswa secara simultan atau bersama-sama.

\section{SIMPULAN}

Terdapat pengaruhsignifikan antara status sosial ekonomi orang tua terhadap minat wirausaha siswa SMP Negeri di Kecamatan Tenggilis Mejoyo Surabaya secara parsial. Hasil temuan pada penelitian ini lebih dominan didukung 
oleh indikator "tingkat pendidikan orang tua". Hal ini dapat ditunjukkan dari temuan bahwa rata-rata tingkat pendidikan yang dimiliki orang tua siswa di SMP 39 dan SMP 17 Surabaya adalah di peruruan tinggi. Terdapat pengaruh signifikan antara literasi ekonomi terhadap minat wirausaha siswa SMP Negeri di kecamatan Tenggilis Mejoyo Surabaya. Hasil temuan pada penelitian ini adalah bahwa untuk litersi ekonomi indikator yang dominan adalah "Pemahaman terhadap prinsipprinsip ekonomi". Terdapat pengaruh signifikan antara percaya diri terhadap minat wirausaha siswa SMP Negeri di Kecamatan Tenggilis Mejoyo Surabaya secara parsial. Hasil temuan pada penelitian ini adalah untuk percaya diri dengan indikator yang dominan yaitu "Berani menyampaikan pendapat". Terdapat pengaruh signifikan sosial ekonomi orang tua, literasi ekonomi, dan percaya diri secara bersama - sama terhadap minat wirausaha siswa SMP Negeri di Kecamatan Tenggilis Mejoyo Surabaya. Ini menunjukkan bahwa sebagai temuan barunya adalah ketiga vaiabel tersebut memberikan pengaruh secara simultan.

\section{DAFTAR RUJUKAN}

Arum Kartika Sari(2013) Pengaruh Peran Orang Tua, Guru dan Self Eficacy Terhadap Kesiapan Berwiusaha Siswa SMK Muhammadiah 1 Bantul Kompetensi Kealiah Audio video Kelas XII, http/eprint uny.ac.id/id eprint 110454

Bustan,J (2014) Pengaruh Prestasi, Locus of Control, ResikoToleransi, Ambiguitas, Percaya Diri dan Inovasi Terhadap Minat Wirausaha Mahasiswa, Jurnal Orasi Bisnis Edisi ke-XI Mei 2014 ISSN: 2085-1375

Collins and Thesaurus. (2006). Advanced learner's dictionary fifth edition. Glasgow: William Collins.

Driyarkara, N. S.J. 1980. tentang Pendidikan,Yogyakarta: Yayasan Kanisius.

Friedman.(2004). Keperawatan Keluarga. Jakarta:EGC

Kumari, Lalita. (2012) A Study of Socio Economic, Self Confident And Problem Faced By Working Women, IOSR Journal Of Humanities And Social Science (JHSS) ISSN: 2279-0837, ISBN: 2279-0845. Volume 3, Issue 4 (Sep. - Oct. 2012), PP 47-50Www.Iosrjournals.Org

Kurt Lewin. (2011). Action Research and Minority Problems. Journal of Social Issues 2 pp. 34-46.

Koichiro, Matsuraa. United Nations Educational, Scientific and Cultural Organization. UNESCO.

Lauster, Peter. 2002. Tes Kepribadian (Alih Bahasa: D.H Gulo). Edisi BahasaIndonesia. Cetakan Ketigabelas. Jakarta: Bumi Aksara.

Arista, Lukmayanti (2015) Hubungan efikasi diri dengan minat berwirausaha siswa kelas XII jurusan jasa boga SMK Negeri 6 Yogjakarta. Thesis. Universitas Negeri Yogjakarta.

Maftukhah. 2007. Pengaruh Kondisi Sosial Ekonomi Orang Tua Terhadap Prestasi BelajarGeografi Siswa Kelas VIII SMP N 1 Randudongkal Kabupaten Pemalang Tahun2006/2007.Semarang: Skripsi S1. Dipublikasikan. Fakultas Ilmu Sosial Universitas Negeri Semarang

Mathews, L. G. (1999) Promoting economic literacy: ideas for your classroom. Paper 
Matsuura, Koichiro. (2006). "Forward", in International Conference Globalization and Education for Sustainable Development Sustaining the Future,(editor:Laura Wong), Paris: UNESCO. 12-13.

Maulida, Siti Rochmah dan Rama Dhania,Dini (2012) Hubungan Kepercayaan Diri dan Dukungan Orang Tua Dengan Motivasi Berwirausaha Pda Siswa SMK, Fakultas Psikologi Universitas Muria Kudus, ejournal.undip.ac.id/index.php/psikologi/article/download/6630/5444

Musthafa, Bacharudin. (2007). Dari Literasi Dini ke Literasi Teknologi. Jakarta:Yayasan CREST.

Riduwan Sunarto (2009) Ststistik Untuk Penelitian Pendidikan,Sosial, Ekonomi, Komunikasi dan Bisnis.Alfabeta. Bandung.

Santoso. (1995). Lingkungan Tempat Tinggal Menentukan Minat Berwirausaha.FKIP. UNS (Laporan Penelitian). Surakarta : UNS.

Schiffman, Leon, \& Kanuk, Leslie Lazar. 2008. Consumer Behaviour 7thEdition (Perilaku Konsumen). Jakarta: PT. Indeks.

Subandono, A. (2007). Pengaruh Life Skill Diklat Kimia Produktif dan Prestasi Belajar Diklat Kewirausahaan terhadap Minat Berwirausaha pada Siswa SMK Kimia Industri Theresiana Semarang. Semarang: Skripsi FMIPA-UNES

Suhartini,Yati (2011) Analisis Faktor-Faktor Yang Mmpengaruhi Minat Mhasiswa Dalam Berwiraswasta. Akmenika UPY, Volume 7, 2011

Sukardi. 2009. Metodologi Penelitian Pendidikan. Jakarta: Bumi Aksara

Soemanto, Wasty. (1992). Sekuncup Ide Operasional Pendidikan Wiraswasta. Jakarta : Gunungjati.

Suryana. (2008). Kewirausahaan Pedoman Praktis, Kiat dan Proses Menuju Sukses. Jakarta : Salemba Empat.

Soetjiningsih.(2004)"Tumbuh Kembang Anak". Jakarta EGC

Syaifullah, Ach. 2010. Tips Bisa Percaya Diri. Jogjakarta: Gerai Ilmu

Wulandari (2011) "Hanya 42,6 Persen Guru Ekonomi Berkualitas Baik". Republika.Edisi 3 April 2011 